\title{
Plutonium Immobilization Program - Cold Pour Phase 1 Test Results
}

by

L. Hamilton

Westinghouse Savannah River Company

Savannah River Site

Aiken, South Carolina 29808

G. Hovis

M. E. Smith

J. W. Won

A document prepared for ANS 2000 at San Diego, CA, USA from 6/4/2000 - 6/8/2000.

DOE Contract No. DE-AC09-96SR18500

This paper was prepared in connection with work done under the above contract number with the $U$. $S$. Department of Energy. By acceptance of this paper, the publisher and/or recipient acknowledges the U.S. Government's right to retain a nonexclusive, royalty-free license in and to any copyright covering this paper, along with the right to reproduce and to authorize others to reproduce all or part of the copyrighted paper. 


\section{DISCLAIMER}

This report was prepared as an account of work sponsored by an agency of the United States Government. Neither the United States Government nor any agency thereof, nor any of their employees, makes any warranty, express or implied, or assumes any legal liability or responsibility for the accuracy, completeness, or usefulness of any information, apparatus, product or process disclosed, or represents that its use would not infringe privately owned rights. Reference herein to any specific commercial product, process or service by trade name, trademark, manufacturer, or otherwise does not necessarily constitute or imply its endorsement, recommendation, or favoring by the United States Government or any agency thereof. The views and opinions of authors expressed herein do not necessarily state or reflect those of the United States Government or any agency thereof.

This report has been reproduced directly from the best available copy.

Available for sale to the public, in paper, from: U.S. Department of Commerce, National Technical Information Service, 5285 Port Royal Road, Springfield, VA 22161

phone: (800) 553-6847

fax: (703) 605-6900

email: orders@ntis.fedworld.gov

online ordering: http://www.ntis.gov/ordering.htm

Available electronically at http://www.doe.gov/bridge

Available for a processing fee to U.S. Department of Energy and its contractors, in paper, from: U.S. Department of Energy, Office of Scientific and Technical Information, P.O. Box 62, Oak Ridge, TN 37831-0062

phone: (865)576-8401

fax: (865)576-5728

email: reports@adonis.osti.gov 


\section{DISCLAIMER}

\section{Portions of this document may be illegible}

in electronic image products. Images are produced from the best available original document. 
National Archives Information:

Tracking Number: 10560 Disposal Authority: N1-434-96-9-1.b(9)(a) Retention Period: Permanent

\section{Plutonium Immobilization Program Cold Pour Phase 1 Test Results (U)}

$\begin{array}{cc}\text { Lee Hamilton } & \text { Dr. Gregg Hovis } \\ \text { Westinghouse Savannah River Company } & \text { Westinghouse Savannah River Co. } \\ \text { Building 773-A } & \text { Building 773-A } \\ \text { Aiken, SC 29808 } & \text { Aiken, SC 29808 } \\ \text { (803) 725-3472 } & (803) \text { 725-1180 } \\ \text { Michael E. Smith } & \text { Jim Wong } \\ \text { Westinghouse Savannah River Company } & \text { Westinghouse Savannah River Co. } \\ \text { Building 773-A } & \text { Building 773-A } \\ \text { Aiken, SC 29808 } & \text { Aiken, SC 29808 }\end{array}$

\section{Introduction}

The Plutonium Immobilization Project will disposition excess weapons grade plutonium. It uses the can-in-canister approach that involves placing plutonium-ceramic pucks in sealed cans that are then placed into Defense Waste Processing Facility canisters. These canisters are subsequently filled with high-level radioactive waste glass. This process puts the plutonium in a stable form and makes it unattractive for reuse. A cold (nonradioactive) glass pour program was performed to develop and verify the baseline design for the canister and internal hardware. This paper describes the Phase 1 scoping test results.

\section{Background}

The Plutonium Immobilization Program (PIP) is a DOE-sponsored joint venture combining the talents of the Savannah River Site (SRS), Lawrence Livermore National 
Laboratory (LLNL), Argonne National Laboratory (ANL), and Pacific Northwest National Laboratory (PNNL) to disposition excess weapons grade plutonium. This program uses the "Can-in-Canister" (CIC) approach. CIC involves encapsulating plutonium in ceramic forms (or pucks), placing the pucks in sealed stainless steel cans, placing the cans in long cylindrical magazines, latching the magazines to racks inside Defense Waste Processing Facility (DWPF) canisters, and filling the DWPF canisters with high-level waste glass. This process puts the plutonium in a stable form and makes it unattractive for reuse.

The DWPF has successfully poured hundreds of empty canisters, so glass flow behavior in empty canisters is well understood. However, the CIC hardware presents a new set of operational concerns. Among these, premature glass freezing and CIC hardware structural integrity are issues that require additional study. Both modeling and test programs are underway to address these issues. Described herein are the results of the first phase (Phase 1) of non-radioactive glass pour tests designed to assess hardware structural integrity and glass flow characteristics under prototypic DWPF conditions. The Phase 1 Test pours are intended to provide scoping quality verification of design concepts prior to the more extensive and quality controlled Phase 2 Tests. The Phase 2 Tests will incorporate changes based on the results of the Phase 1 Tests and verify the adequacy of the baseline design.

\section{Discussion}

The objective of Phase 1 testing was to observe the effects of the glass on the hardware, and vise versa. The Phase 1 cold pours tested three hardware configurations. All three configurations consisted of fully equipped DWPF canisters (i.e. internal rack and full 
compliment of magazines and cans). Three rack designs, eight magazine designs, and two lateral latching configurations were tested in the Phase 1 pours. Each rack carried seven magazines, and each magazine held four cans. All internal hardware (rack, magazines, and cans) was made of 304L stainless steel. The cans were loaded with either non-radioactive titanate-based ceramic pucks (fabricated by LLNL), ceramic surrogate logs, or stainless steel bars. The ceramic pucks could not be used exclusively because not enough were available in time for the test. Therefore ceramic logs (Harbison-Walker Aurex 90 chrome-alumina brick) were used because their thermal properties were similar to the ceramic pucks. These ceramic logs were lighter than the pucks, therefore stainless steel bars were installed in appropriate can locations to simulate the effects of a full weight magazine. For these tests, the racks were configured with four different magazine types. Three of the magazine types were arranged in pairs (taking up six positions) and a fourth type was placed in the seventh position. Magazine pairing was done to observe glass flow between like magazine types. Finally, two canister assemblies were filled with simulated DWPF waste glass. Typical magazine and rack designs are shown in Figures 1 and 2.

\section{Test Results}

Phase 1 test results consist of temperature measurements, observation of glass flow, and hardware deformation measurements.

\section{Temperature Measurements}

One of the three test configurations was instrumented (23 thermocouples, digital video camera, and scale). Both glass and metal temperatures were measured at various heights and radial locations. Figure 3 shows glass temperatures at various heights, measured 
roughly 6" from the center of the canister. This figure gives a good indication of maximum glass temperatures inside the canister. Can temperatures were also measured, and Figure 4 shows temperature data taken from the can OD on the inboard side. This temperature reading is an important parameter is determining can material strength and internal pressure. Preliminary modeling showed that temperatures must exceed $1100 \mathrm{C}$ to affect can structural integrity. As shown in Figure 4, can temperatures stayed below $900 \mathrm{C}$.

\section{Glass Flow}

Digital video recorded during the pour and post-test destructive analysis were used to assess glass flow.

A video recording taken during the pour provided larger-scale visual information on glass flow phenomena. Frames from that recording are shown in Figures 5 and 6 . Figure 5 shows the pour just beginning. Figure 6 was taken at a glass height of approximately 6", and glass can be seen flowing over the rack's lower plate. No voiding or premature glass freezing was observed.

Post-test destructive analysis consisted of making radial cuts at different elevations through each of the test canisters using either a diamond wire saw or large band saw. These cuts exposed glass and metal cross-sections for inspection. Figure 7 shows a typical cutaway. Figure 8 is a closer look at a magazine and can. A visual examination verified that the simulated waste glass filled small crevices in the magazine and completely filled the annular spaces between the magazines and cans, indicating good glass flow. 


\section{Hardware Deformation Measurements}

In addition to thermal and glass flow data, spatial measurements of canister hardware were made. Dimensions such as magazine $O D$, can $O D$, support rod $O D$, and support rod spacing were taken at each of the exposed cut faces. These measurements verified that the CIC hardware did not experience measurable plastic deformation during the pour or later as the glass cooled.

\section{Conclusions}

Favorable results were achieved in the PIP Phase 1 cold pour test program. No voiding was observed, and glass appeared to have filled all spaces in the canister including small crevices between steel parts. No measurable plastic deformation was observed in any of the CIC hardware. 


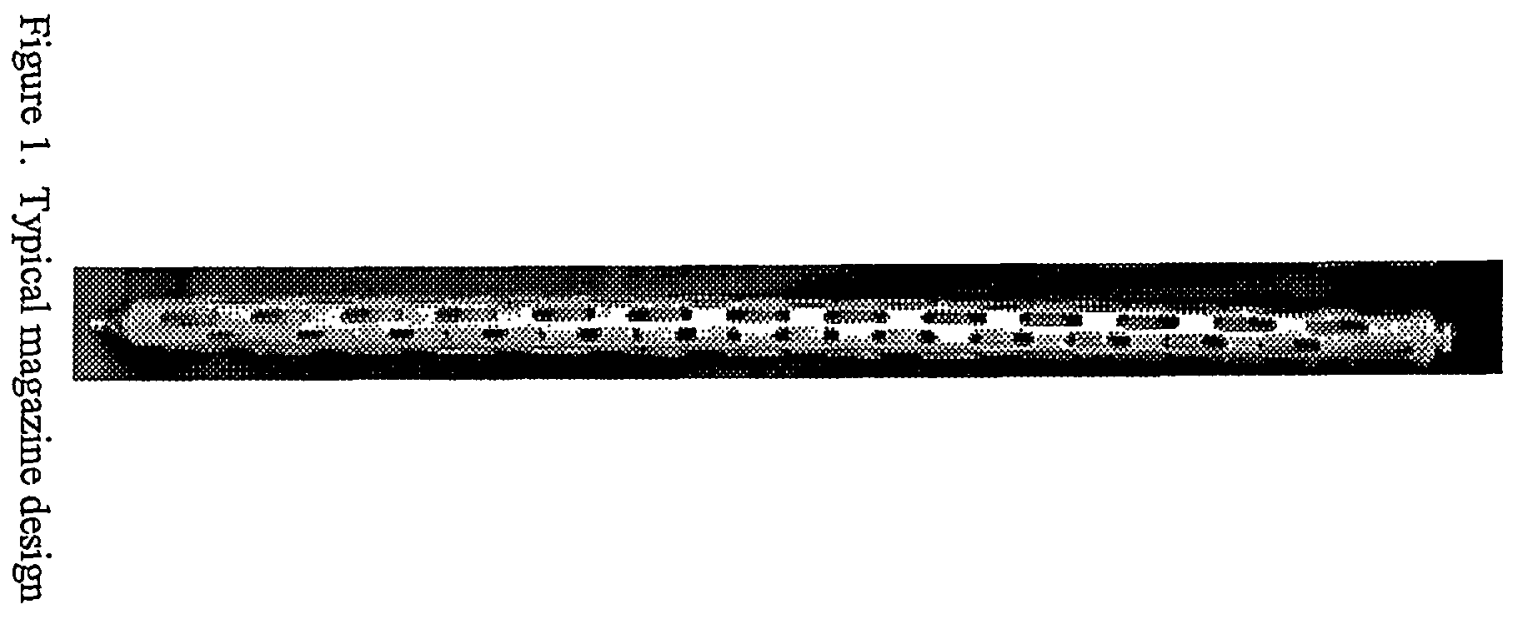

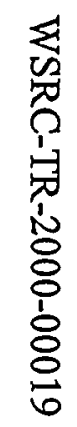

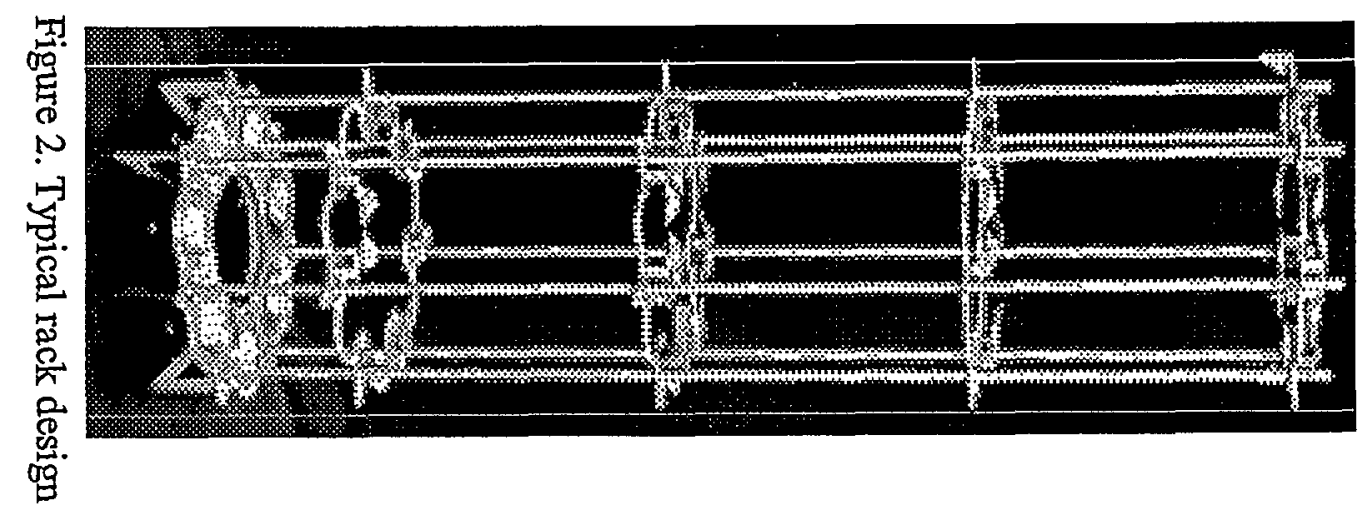




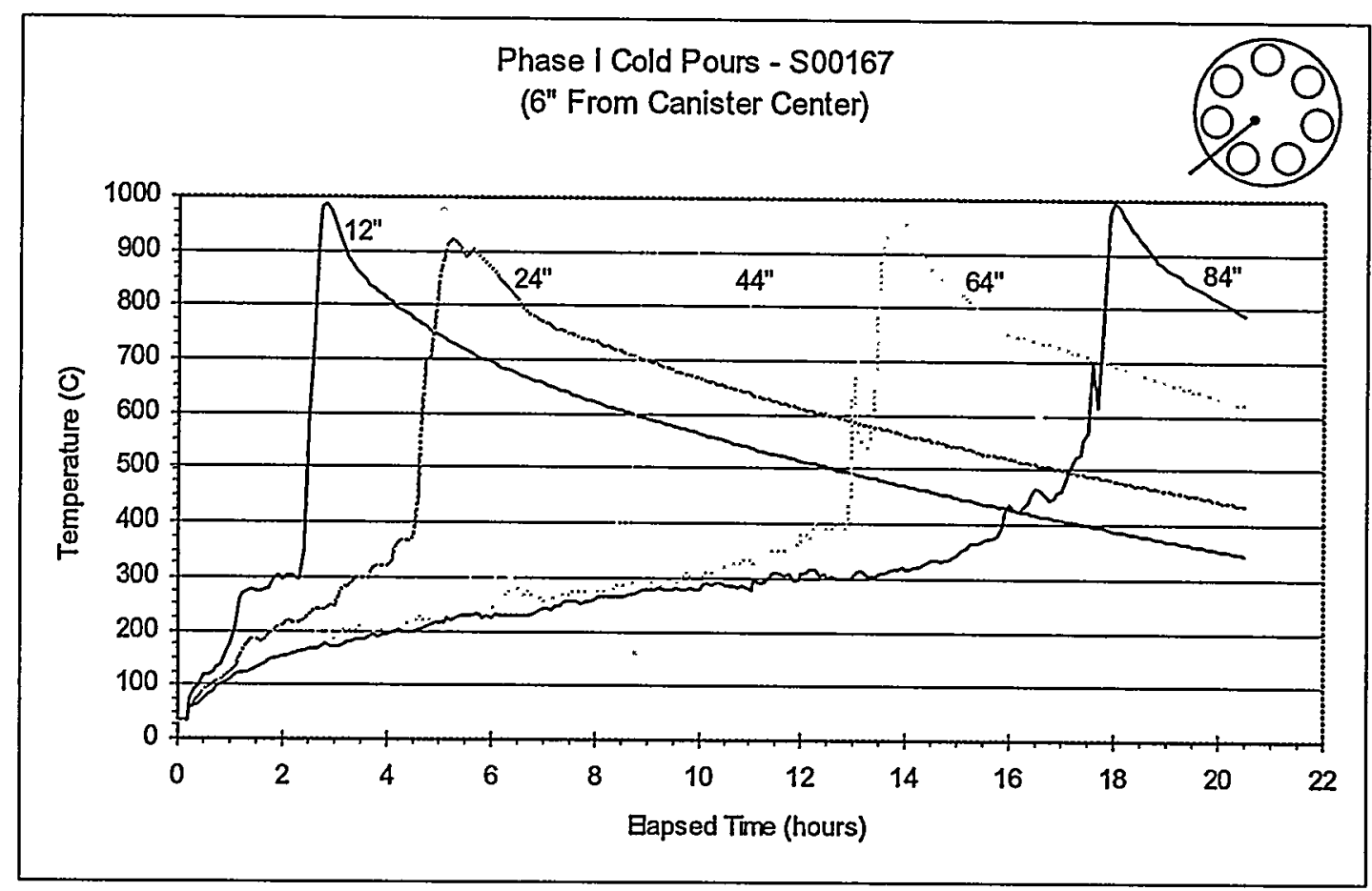

Figure 3: Glass temperatures at various heights (height measured from canister bottom).

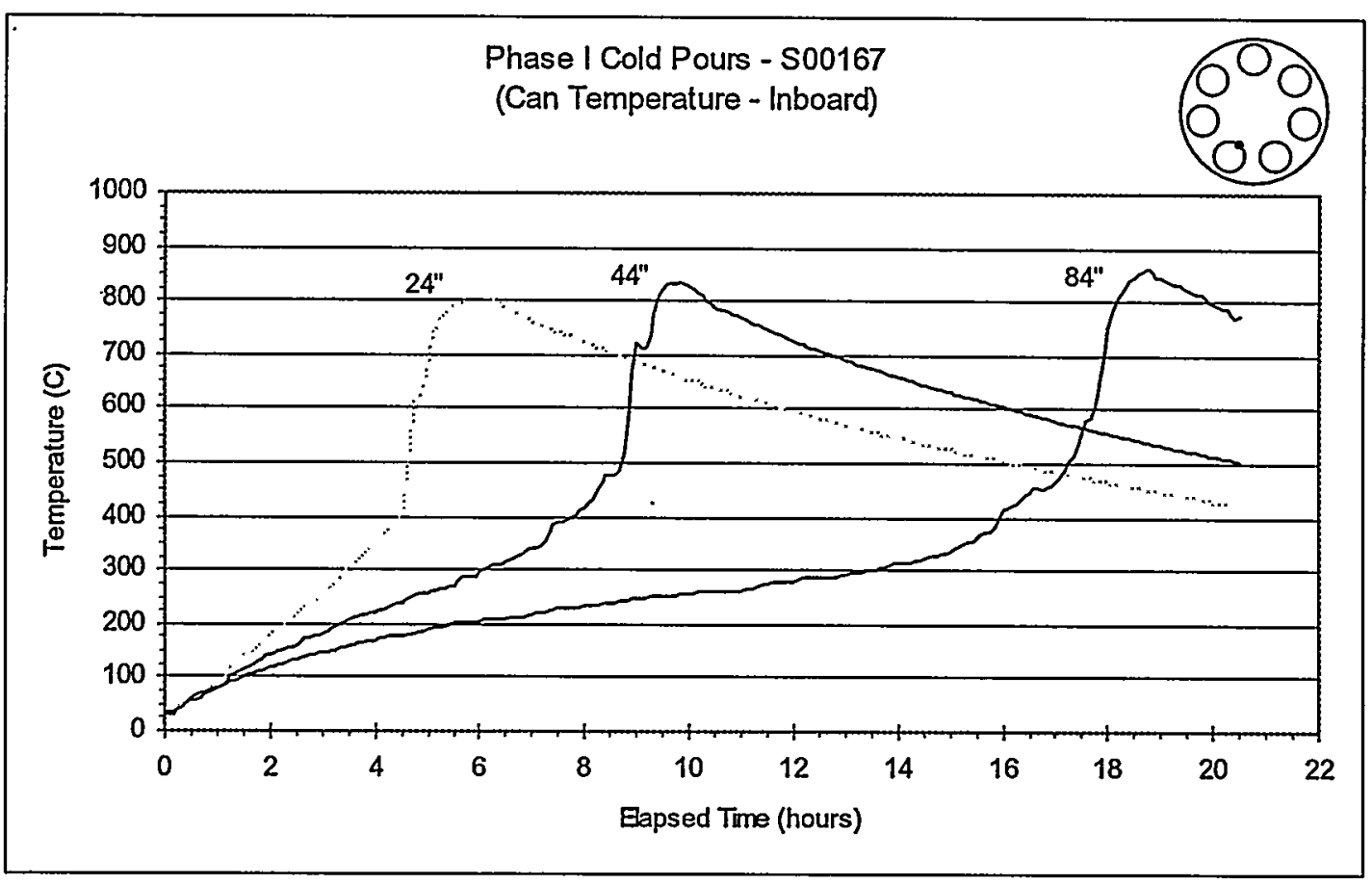

Figure 4: Can temperatures at various heights (height measured from canister bottom). 


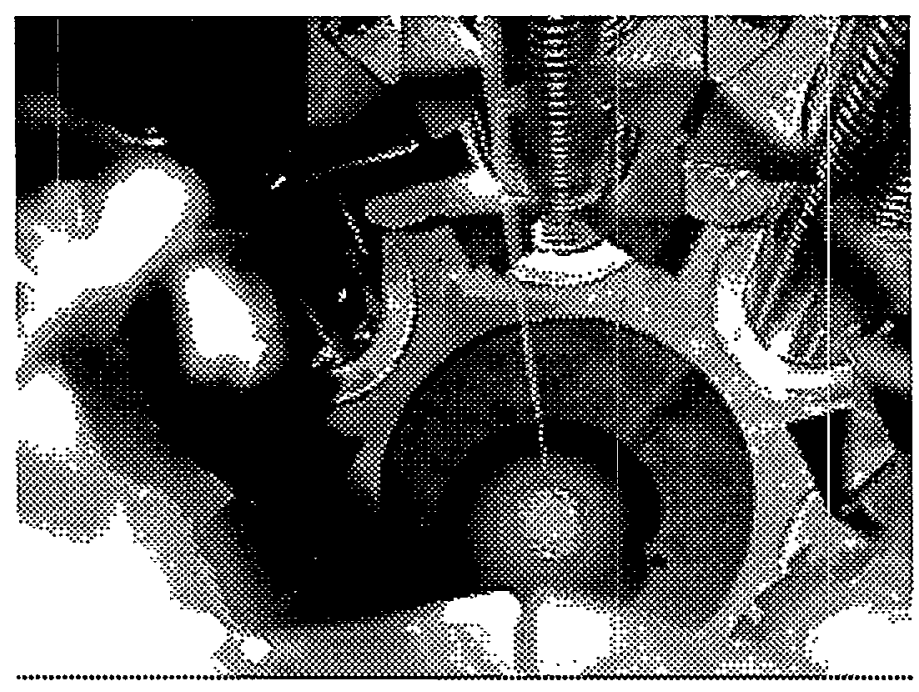

Figure 5: Glass pour video (beginning of pour).

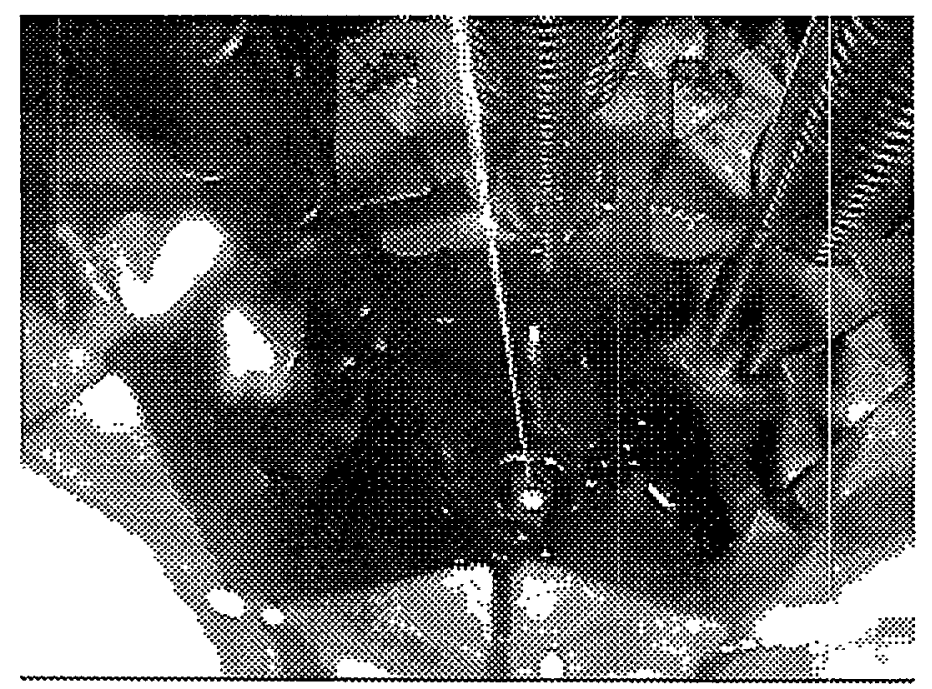

Figure 6: Glass pour video (fill height $\sim 6 "$ "). 


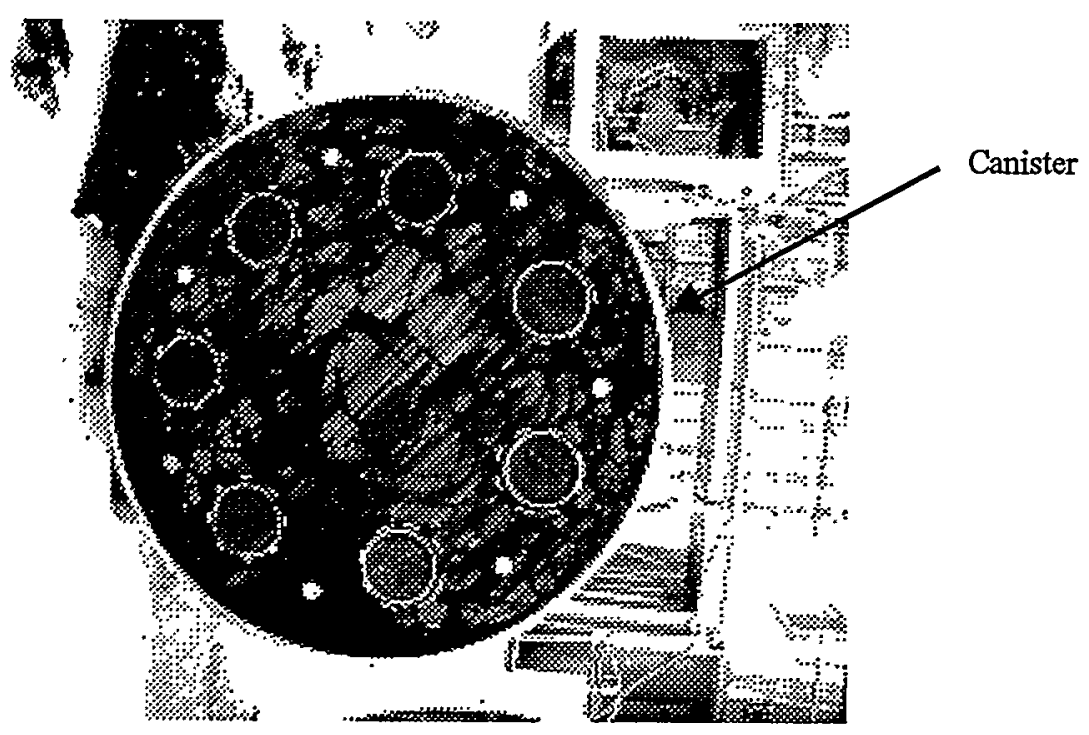

Figure 7: Typical canister cutaway.

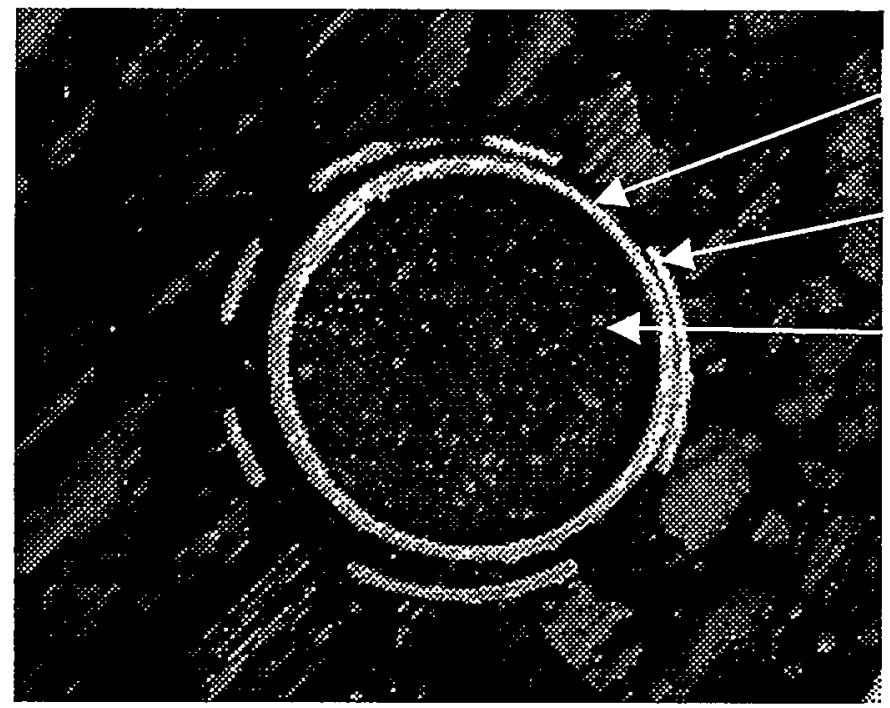

Can

Magazine

Surrogate Ceramic Log

Figure 8: Close-up of magazine and can. 